\title{
EFFECTS OF PARENTAL BACKGROUND ON OTHER-REGARDING PREFERENCES IN CHILDREN
}

\author{
Michal Bauer \\ Julie Chytilová \\ Barbara Pertold-Gebicka
}
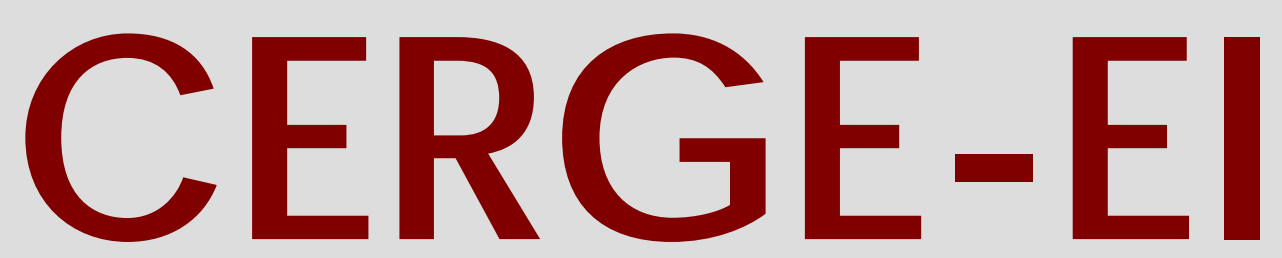

Charles University CenterforEconomic Research and Graduate Education Academy of Sciences of the Czech Republic Ec onomic s Institute 


\title{
Working Paper Series 450 (ISSN 1211-3298)
}

\section{Effects of Parental Background on Other-regarding Preferences in Children}

\author{
Michal Bauer \\ Julie Chytilová \\ Barbara Pertold-Gebicka
}

CERGE-EI

Prague, October 2011 
ISBN 978-80-7343-253-9 (Univerzita Karlova. Centrum pro ekonomický výzkum a doktorské studium)

ISBN 978-80-7344-245-3 (Národohospodářský ústav AV ČR, v.v.i.) 


\title{
Effects of Parental Background
}

\section{on Other-regarding Preferences in Children ${ }^{*}$}

\author{
Michal Bauer ${ }^{+}$ \\ CERGE-EI and Charles University in Prague \\ Julie Chytilová ${ }^{++}$ \\ Charles University in Prague \\ Barbara Pertold-Gebicka \\ Charles University in Prague and Aarhus University
}

\begin{abstract}
Other-regarding preferences are central for the ability to solve collective action problems and thus for society's welfare. We study how the formation of other-regarding preferences during childhood is related to parental background. Using binary-choice dictator games to classify subjects into other-regarding types, we find that children of less educated parents are less altruistic and more spiteful. This link is robust to controlling for a range of child, family, and peer characteristics, and is attenuated for smarter children. The results suggest that less educated parents are either less efficient to instill social norms or their children less able to acquire them.
\end{abstract}

Keywords: other-regarding preferences, altruism, spite, experiments with children, family background, education

JEL Classification: C91, D03, D64, I24

\footnotetext{
* We thank M. Choi, R. Filer and Š. Jurajda for helpful comments and K. Bát’a, J. Cahlíková, J. Hercher. I. Levely and J. Palguta for excellent research assistance. We are grateful to principals of cooperating schools and kindergartens for their support. The research was supported by a grant from the CERGE-EI Foundation under a program of the Global Development Network, by an institutional grant 0021620841 of the Ministry of Education of the Czech Republic and by the Czech Science Foundation (P402/10/P103, P402/10/P105). While working on this paper, Bauer was supported by a research center grant LC542 of the Ministry of Education of the Czech Republic implemented at CERGE-EI. All opinions expressed are those of the authors and have not been endorsed by any of the organizations with which we are affiliated or which sponsored the research. All errors remaining in this text are the responsibility of the authors.

${ }^{+}$CERGE-EI is a joint workplace of the Center for Economic Research and Graduate Education, Charles University, and the Economics Institute of the Academy of Sciences of the Czech Republic.

${ }^{++}$Contact details: Julie Chytilová, Charles University in Prague, Institute of Economic Studies, Opletalova 26, Prague 1, 101 00, Czech Republic. Email: chytilova@fsv.cuni.cz
} 


\begin{abstract}
Abstrakt
Sociální preference jednotlivce hrají klíčovou při rozhodování zda spolupracovat a tudíž pro blahobyt společnosti. V tomto článku studujeme, zda a jak formování sociálních preferencí souvisí se socio-ekonomických statutem rodičů. Série experimentálních her nám umožňuje děti klasifikovat podle typu jejich sociálních preferencí. Zjistili jsme, že děti méně vzdělaných rodičů jsou méně altruistické a více závidí. Efekt vzdělání rodičů je zeslaben u dětí, které mají vysoké kognitivní schopnosti. Tyto výsledky implikují, že méně vzdělaní rodiče jsou bud' méně efektivní při vštěpování sociálních norem svým dětem či jejich děti méně schopné tyto normy internalizovat.
\end{abstract}




\section{Introduction}

Identifying the effects of parental socio-economic background on formation of preferences and skills during childhood is central for understanding the sources of persistent inequality across social groups (Samuel Bowles, Herbert Gintis, and Melissa Osborne Groves 2008; James J. Heckman 2006). Recent research (Flavio Cunha and Heckman 2007; Cunha et al. 2006; Heckman 2006) provides two important insights: (1) family environment plays an important role in formation of cognitive and non-cognitive skills ${ }^{1}$ which are important predictors of individual success in life, such as lower participation in crime, better health, higher educational achievement or more wealth, and (2) gaps in these skills associated with parental background emerge early in childhood and are persistent. This literature has important policy implications for the timing of investments in children coming from disadvantaged environments.

While the existing research has focused on understanding the role of parental background on skills and preferences that facilitate individual success, we know very little about the role of parental background in the formation of preferences that concern welfare of others. This is what we study in this paper. The prevalence and type of other-regarding preferences are crucial for the ability to solve various collective action problems in large groups, and therefore for achieving higher welfare in a society. A positive spectrum of other-regarding preferences - altruism, inequality aversion, or efficiency concerns - helps to establish and maintain cooperative outcomes (Bowles 2004; Ernst Fehr and Urs Fischbacher 2003), while spitefulness, observed among a non-negligible proportion of adult subjects, motivates punishment of cooperative group members and leads to deterioration of co-operation (Armin Falk, Fehr, and Fischbacher 2005; Benedikt Herrmann, Christian Thoni, and Simon Gaechter 2008). Surprisingly, however, very little is known about whether parental socio-economic background affects the type and intensity of other-regarding preferences that children acquire because experimental measures of child preferences have so far not been complemented with survey information about the background of their parents. A priori, there are numerous plausible pathways why a child's other-regarding preferences may be affected by the background of her parents: differences in parental socialization practices, genetic predispositions to acquire social norms, individual characteristics that may facilitate

\footnotetext{
${ }^{1}$ Non-cognitive skills encompass traits such as patience, self-control, motivation and persistence (Cunha et al. 2006).
} 
formation of preferences such as cognitive skills and health, or differences in peers and teachers with whom a child interacts at home and in school.

We combine experimental measures among children and parental survey data to study the link between parental education and social preferences and we test some of the possible pathways that may explain such a link. We use a set of four simple binary choice dictator games that allow us to classify subjects into different other-regarding types: altruism, inequality aversion and spitefulness in their weak and strong form. Altruistic types assign a positive value to another person's payoff, egalitarian types prefer allocations that minimize differences in payoff, while spiteful types assign a negative value to other person's payoff. Our sample consists of 275 children from the Czech Republic, distributed across the age range of 4-12 years. In addition to experimental measures of other-regarding preferences, we collect measures of child cognitive skills and health, and survey information about family environment in terms of education and employment status of parents, whether parents live together, and sibling's composition. To the best of our knowledge, this is the only study to date exploring whether parental background can explain developmental gaps in otherregarding preferences.

Our study is related to two streams of literature. First, previous studies have made progress in addressing an important question how other-regarding preferences develop during childhood and adolescence. ${ }^{2}$ Older children are found to take the welfare of others into account more often than younger children (Fehr, Helen Bernhard, and Bettina Rockenbach 2008; William T. Harbaugh, Kate Krause, and Steven J. Liday 2003), although the precise notion of fairness seems to alter during adolescence (Ingvild Almås et al. 2010; Fehr, Daniela Ruetzler, and Matthias Sutter 2011). Specifically, Fehr, Bernhard, and Rockenbach (2008) find that selfishness dominates among the youngest children and inequality aversion develops strongly up to the age of 8 years. Fehr, Ruetzler, and Sutter (2011), using the same experimental methodology in a different setting, find that a weak form of altruism develops during the age range of 8-17 years, while spiteful motives diminish during this period. These findings suggest that individuals acquire much of their social behavior during the period of socialization which starts within families and continues in schools. It has been argued that early childhood, when children are most impressionable, is the most crucial phase in this process (Avinash Dixit 2009; Nancy Eisenberg and Richard A. Fabes 1998).

\footnotetext{
${ }^{2}$ Experimental tools have been increasingly used to study development of preferences during childhood and adolescence: risk aversion (Catherine C. Eckel et al. 2011; Harbaugh et al. forthcoming; Sutter et al. 2010), time discounting (Eric Bettinger and Robert Slonim 2007; Sutter et al. 2010), trust (Harbaugh et al. 2002; Sutter and Martin Kocher 2007).
} 
Second, the recent literature suggests that parental background may play an important role in the process of formation of other-regarding preferences during this sensitive period. In an influential cross-cultural study, Joseph Henrich et al. (2005) find large variation in pro-social behavior across different societies. The authors infer that adults in these societies are likely to socialize their children in different ways. In the context of our study, we hypothesize that more educated parents invest more effort to teach their children to acquire cooperationenhancing traits and/or are more efficient in doing so as compared to parents with lower education levels. Sociological studies also argue that differences in parental socioeconomic status are associated with several important differences in socialization practices, including less consistent and supporting parenting practices, higher levels of violence, and less parental monitoring among parents with lower status (for an extensive review see Gary W. Evans, 2004). Closest to our study, Joyce F. Benenson, Joanna Pascoe, and Nicola Radmore (2007) find that children from impoverished neighborhoods in the UK are less likely to share in a dictator game as compared to children from richer neighborhoods, but they do not collect individual-level data to explore whether this is related to parental background or some features of the environment which may be related to parental background and affect otherregarding preferences. There may be various indirect channels through which parental background could potentially affect other-regarding preferences. Disadvantaged parental background has been found to be negatively related to child cognitive and non-cognitive abilities (Alison Aughinbaugh and Maury Gittleman 2003, Bjorn Bartling, Fehr, and Daniel Schunk forthcoming; Cunha et al. 2006), child health (Anne Case, Darren Lubotsky, and Christina Paxson 2002; Janet Currie 2009), school quality, and associated effects of peers or teachers (Case and Lawrence F. Katz 1991).

Our study contributes to the existing literature in two ways. First, we find that children from families where both parents have low education are less altruistic and more spiteful. These results suggest that parental socio-economic status affects gaps in other-regarding preferences already in childhood and mirror previous findings about effects of parental background on cognitive and non-cognitive skills. Second, our data set allows us to partially open the "blackbox" of these parental effects and to test some of the possible pathways between low parental education and less pro-social preferences of children. The relationship between parental education and child other-regarding preferences is robust to controlling for siblings' composition, class fixed effects, maternal employment status, whether both parents live together or separated, and measures of child health, suggesting that our results are not driven by peer effects associated with parental choice of school, the intensity of parental care, or 
child health. Interestingly, the gap associated with low parental education is particularly profound among children with low cognitive skills, and it is virtually absent for brighter children. There is also no gap for children with low cognitive skills but highly-educated parents. Taken together, our results are most consistent with the possibility that parents with low education are less efficient in instilling preferences that comply with social norms or that their children are, perhaps for genetic reasons, less able to acquire those norms.

The rest of the paper is organized as follows. In section II we describe the experimental design and the sample. In Section III we discuss the results. Section IV concludes.

\section{Experimental and Survey Design}

\section{A. Eliciting Other-Regarding Preferences}

We measure other-regarding preferences using a series of four binary choice dictator games, inspired by the protocol of (Fehr, Bernhard, and Rockenbach 2008). ${ }^{3}$ In each game, a subject has to select between two alternative allocations of tokens for herself and a partner. From different combinations of choices across these four games, we can classify subjects into types of other-regarding preferences as predicted by theory: altruistic, inequality-averse and spiteful. We distinguish between a weak and a strong form of these preferences, depending on whether a subject is willing to sacrifice individual payoff to alter the payoff of her partner. Note that these are one-shot experiments without repeated interactions and partners are always anonymous. Thus, the experimental design rules out the potential for future reciprocal behavior and isolates other-regarding preferences from strategic considerations to receive future benefits.

In the costly prosocial game, a subject chooses between the allocation $(1,1)$---one token for herself and one for partner--- and the allocation $(2,0)$---both tokens for herself. This game measures preference to reduce inequality (Gary E. Bolton and Axel Ockenfels 2000; Fehr and Klaus M. Schmidt 1999) or altruism. Because choosing the egalitarian option (1,1) provides a benefit to an anonymous partner at a cost to oneself, a purely selfish subject should never make the egalitarian choice. In the costless prosocial game, the subjects can choose between $(1,1)$ and $(1,0)$. Choosing the $(1,1)$ option indicates the basic prosociality because it is costless

\footnotetext{
${ }^{3}$ A similar set of mini-dictator games was also used by Bauer, Chytilová, Alessandra Cassar and Henrich (2011) to estimate the effects of exposure to warfare on other-regarding preferences of children in the Republic of Georgia.
} 
to increase a partner's payoff, and choosing the $(1,1)$ option is consistent with models of inequality aversion, maximization of efficiency (Gary Charness and Matthew Rabin 2002) or pure altruism. In the costless envy game, the decision-maker can choose between $(1,1)$ and $(1,2)$. Choosing the $(1,1)$ option indicates aversion to disadvantageous inequality or spitefulness (minimization of partner's payoff). Relative to Fehr, Bernhard, Rockenbach (2008), we enrich the experimental setup by the costly envy game [(1,1) vs. $(2,3)]$ which is a natural complement to the costless envy game $[(1,1)$ vs. $(1,2)]$, similarly as the costly prosocial game $[(1,1)$ vs. $(2,0)]$ complements the costless prosocial game $[(1,1)$ vs. $(1,0)]$. In this game, the unequal choice leads to a higher reward for both players, but it also creates disadvantageous inequality for the decision-maker. Thus, because the egalitarian allocation is costly for the decision-maker, it indicates strong preference to reduce inequality or spitefulness. The payoffs of all four games are summarized in Table 1.

The two mutually exclusive options in these games were represented on two cardboards (see Fig. A1). On each cardboard there were two circles, each one with one arrow directed either to the decision-maker or to an anonymous partner coming from a pool of children displayed on a laptop screen. We placed the tokens inside the circles. An arrow directed towards the decision-maker illustrated that (s)he would be the recipient of the tokens placed inside that circle, whereas the tokens in the other circle, with an arrow towards the laptop picture, illustrated how much the partner of a similar age would receive. ${ }^{4}$

Pooling choices across all four games allows for the classification of subjects according to their type of other-regarding preferences into six groups (detailed in Table 1). We classify them to be Strongly altruistic if they maximized the payoff of their partner in all four games, including the costly prosocial game when increasing a partner's payoff is costly. Weakly altruistic children maximize the payoff of their partner in all games except the costly prosocial game. Strongly inequality-averse children minimize differences in payoffs by choosing the egalitarian option in all four games. Weakly inequality-averse children choose the egalitarian option only in the costless prosocial and costless envy games and maximize their payoff in the costly games. Strongly spiteful children minimize their partner's payoff in all games, while Weakly spiteful children minimize their partner's payoff only when it is not costly for them, thus in all games except the costly envy game.

\footnotetext{
${ }^{4}$ Children were randomly assigned to one of four treatments which differed in terms of their partner's identity (a classmate, an unknown partner from an unknown class, a Vietnamese child or a Roma child). The design allows assessing whether other-regarding preferences vary with the familiarity and ethnicity of the recipient. Such an analysis is beyond the scope of this paper.
} 
The experimental choices were made privately and only the experimenter could observe the subject's decision (it is nearly impossible to conduct a double blind protocol with small children). The experimenters explained to each child that nobody, including their parents and teachers, would be informed about their choices (instructions are available upon request). Prior to making choices in each task, the children had to correctly answer a set of questions about the payoff consequences of each option to ensure their understanding. The order of the games, the allocation of the egalitarian option on either the right hand side or the left hand side, the experimenter (out of three), and the treatment were randomly determined before the actual experiment. The results reported in this paper are robust to controlling for order effect, spatial allocation of the egalitarian option, the experimenter effect and the identity of an always anonymous partner [not reported, results available upon request].

The children were motivated to reveal their preferences. During the experiments they received tokens according to their choices. The tokens for a partner were put aside in a paper bag and anonymously delivered later. After the experiments were completed, children exchanged tokens for various kinds of sweets, pencils, erasers, stickers and small toys in an experimental shop which we set up at the site (see Figure A2). For simplicity, the price was always one token for one item. To increase the salience of rewards, each subject received one token as a show-up fee and exchanged it for a reward prior to making experimental choices. All rewards were given to the children immediately after the experiment and placed into a paper bag. We requested the children not to open the bag before the end of the school-day so that other classmates could not observe its content before participating in the experiments.

\section{B. Sample and Non-Experimental Data}

The experiments took place in the Czech Republic, a country in Central Europe and a European Union member, with recent history of transition from a post-communist to market economy. Our subjects come from seven primary schools and four kindergartens located in Prague, the capital city, and villages close to Prague. The headmasters of participating schools were provided with explanations of the experiments and gave official permission to conduct the experiments. ${ }^{5}$ The headmasters informed parents about the study which was described as a research project in decision-making without referencing any details about the actual

\footnotetext{
${ }^{5}$ The headmasters were requested not to describe, instruct or make any reference about the experiments to the children and their teachers prior the actual implementation. Based on conversations with teachers during the implementation, this request was followed.
} 
experiments. In several cases, when schools had previous experience with researchers, headmasters did not ask for parental consent for this particular project. ${ }^{6}$ The experiments took place in schools and kindergartens during usual school days, to mimic an environment natural for this subject pool and to eliminate the problem of self-selection into participation in our experiments. In this paper we study a sample of 275 children who participated in the experiments and whose parents answered our survey questionnaire. ${ }^{7}$ Table 2 provides summary statistics of the sample.

Besides experimental measures of other-regarding preferences, we collected data about children's age, gender, cognitive skills, health and family background. Age is measured in years; nevertheless for the purpose of specific analysis we divide our sample into two aggregate groups: younger (aged 4-7) and older (aged 8-12) children. ${ }^{8}$ For cognitive skills and health we use measures that indicate relative position of a child with respect to her peers.

We have three measures of cognitive skills at hand. The first measure of cognitive skills is IQ measured by a set of Raven's Progressive Matrices (John Raven 1948), a widely used nonverbal test of intelligence (an example is provided in Figure A3). The advantage of this measure is that it is generally perceived as a relatively pure measure of IQ because it captures the ability to solve novel problems (Lex Borghans et al. 2010). The IQ tests were administered by Mensa Czech Republic - a branch of Mensa International. ${ }^{9}$ In the data analysis, we use a dummy variable "Low IQ" which is equal to one if a child answered correctly fewer questions than is the median among children of the same age. The IQ measure is available for a sub-sample of 140 children. The sample is reduced because the test is designed for children who are at least 5 years old and not all parents gave their consent to

\footnotetext{
${ }^{6}$ The experiments were also approved by the Director of the Institute of Economic Studies, Faculty of Social Sciences at Charles University, to substitute for lacking Human Subject Review Boards in the Czech university system.

7 We collected experimental data among 438 children attending kindergartens and lower level of primary schools (up to grade 5). We believe this sample is largely representative of the area we study. A questionnaire was sent to the parents of these children to collect information about their family background. Parental response rate was $64 \%$ and we excluded children whose parents did not fill out the questionnaire. Two parents filled the questionnaire but did not provide information about their education level and were also excluded from the analysis. Sample selection due to parental non-response is unlikely to affect our main estimates. None of the choices in the games or individual characteristics except age is significantly different between the sub-sample of children included in and excluded from the analysis. Children whose parents filled the questionnaire are on average half a year younger than children whose parents did not fill the questionnaire. We perform several robustness checks (e.g. Heckman sample selection model, see Appendix Table A2) and conclude that our results are not affected by patterns in parental non-response.

${ }^{8}$ The age of 8 is chosen as the dividing threshold because it is the median age in our sample.

${ }^{9}$ Mensa uses tests with different numbers of questions and difficulty levels for different age groups. In our case, children up to 7 years of age answered a test which contained 36 questions and older children answered a test with 60 questions. Note that we adjust the IQ measure is adjusted for age.
} 
participation in the tests. ${ }^{10}$ The next two measures of cognitive skills are children's grades in mathematics, which we obtained from schools, and teachers' subjective assessment of each child's school performance collected via a survey for the teachers. Both are less pure measures of cognitive skills than IQ since school performance is a complex outcome of not only cognitive skills but learning abilities in general. The advantage is that these measures are available for different sub-samples of children than IQ and allow us to run robustness checks. Grades in mathematics are available for most of the children in the 2 nd to 5 th grade (133 children), while teacher assessment of children's performance is available for all pupils except kindergarteners (200 children). Similarly as in the case of IQ, we divide the sample into low and high cognitive ability groups, specifically children who achieved grade $\mathrm{A}$ in mathematics at the end of the year preceding the experiment, and children who achieved lower grades; and children who are assessed by their teachers as performing very well or well (high performers), and those assessed to have average, weak or very weak performance (low performers).

We use two measures of children's health - their height measured by the experimenters and absence at school. The variable "Below median height" equals to one if the child's height is below the median height of the children in our sample of the same age and gender. ${ }^{11}$ The variable "High absence at school" is equal to one if the child missed more school hours than is the median absence in our sample. ${ }^{12}$

To measure parental socio-economic status and family environment, we carried out a survey among parents of the participating children. The collected data include their education level, employment status of mother, whether the child lives with both parents, the number of child's siblings and birth order of the child. These measures constitute proxies for the intensity of parental care and social interaction during childhood. In the data analysis, one of our major variables of interest is "Low parental education" which is equal to one if both parents have either primary school or secondary school without leaving exam, and is equal to

\footnotetext{
${ }^{10}$ Mensa requested consents specific for the IQ tests because IQ is particularly sensitive personal information. Half of the parents of children eligible for the test agreed with the test. None of the individual and family characteristics reported in Table 2 differs significantly between the sub-samples of children for whom we have the IQ measure and for whom we do not have it.

${ }^{11}$ Fourteen children did not feel comfortable when the experimenters wanted to measure their height and this variable is missing for them.

${ }^{12}$ Schools report two types of absence of students: missing school hours that are ex post approved by their teacher, typically for health reasons after showing a confirmation from a doctor, and missing school hours that are not approved. In the analysis we use "approved absence", because this information captures more closely a child's health status, while unapproved absence is most likely driven by a child's misbehavior. The measure of absence at school is available for 117 children.
} 
zero if at least one parent has completed secondary school with leaving exam. ${ }^{13}$ Previous research has shown that in the intergenerational transmission of personality and attitudes, the mother's characteristics often play a more important role than the father's characteristics (for a review see John Loehlin 2005). We focus on the overall effect of parental education since education levels of mothers and fathers in our sample are highly correlated $(0.638, p=0.000)$. However, all the results are robust to using mother's and father's education instead of parental education.

\section{Results}

\section{A. Does Family Background Matter?}

We find children of less educated parents to be less willing to share. While the proportion of children who decide to share by choosing the egalitarian option in the costly prosocial game is $33 \%$ for the children of less educated parents, it is $49 \%$ for the children from more educated families. Table 3, panel A, column 1 demonstrates this effect in a regression framework, where we control for other parental characteristics, and child's age and gender. Qualitatively similar effects of parental education are obtained in the costless prosocial game $[(1,1)$ vs. $(1,0)]$, although the coefficient is smaller and statistically insignificant (column 2 ). We find no effect on choices in the envy games $[(1,1)$ vs. $(2,3)$, and $(1,1)$ vs. $(1,2)]$. The results are robust to replacement of parental education by mothers' and fathers' education [see Appendix Table A1]. Interestingly, the fact that parents live separated and a mother has a fulltime job does not correlate with choices in any of the four games.

Next, we analyze the prevalence of six other-regarding types, as defined in Section II.A based on choices across the four games (see Table 1). In Panel B of Table 3 we show that children of less educated parents are more likely to exhibit less cooperative types of otherregarding preferences. First, in columns 1 and 2 we observe that the intensity of altruistic motives is smaller for children of less educated parents: they are less likely to be strongly altruistic but more likely to be weakly altruistic. The magnitude of these effects is similar,

\footnotetext{
${ }^{13}$ The school leaving exam - called the maturity exam - is considered as a label of an educated person. It is a prerequisite for applying to a college, university, or other higher education institution. Secondary education without school leaving exam corresponds to level 3 of the International Standard Classification of Education (ISCED), while secondary school with leaving exams corresponds to level 4. In 2009 there were 4.2 million people over the age of 15 in the Czech Republic who have completed this education level. Out of those, 1.5 million of people have completed college. To compare, there were 4.8 million people without the school leaving exam (Czech Statistical Office 2010).
} 
around 11 percentage points. Second, children of less educated parents are more likely to be weakly spiteful, i.e., to minimize the payoff of their partner unless it reduces their payoff. The effect is statistically significant (column 5). We find no correlation between parental education and prevalence of inequality-averse types (columns 3, 4).

\section{B. Studying Pathways: The Role of Cognitive Skills, Health and Peers}

In principle, there can be multiple pathways other than parental socialization practices through which family background can influence other-regarding preferences of children. In the following analysis we explore three important candidates: health, cognitive abilities and peer effects. As noted, previous research has found parental background to correlate with cognitive abilities and health status of children. If healthier and/or smarter children have different social behavior, parental education may be observed to influence other-regarding preferences indirectly via these characteristics. Parental education may also affect selection and characteristics of a child's companions with whom she regularly interacts either at home or in kindergarten and at school. More educated parents may be more likely to have fewer children, which may limit their children's social interaction with peers of similar age during early childhood. At the same time, they may reside in different locations and choose better schools, thus affecting the composition of teachers and classmates with whom their child regularly interacts and from whom she learns. To test whether the relationship between parental education and child's other-regarding preferences observed in our data is driven by any of these channels, we repeat the estimations controlling for health, cognitive abilities ${ }^{14}$, and siblings' composition, as well as for class fixed effects.

First, we study how our health measures relate to choices in the games. Columns 1-4 of Panel A of Table 4 show that children with low height or greater absence rate in school do not differ in their other-regarding preferences from taller and less sick children. In columns 5-8 we control for low IQ to see whether children with lower cognitive skills make systematically different choices in the games as compared to brighter children. It turns out that worse abstract logical thinking captured by the IQ measure does not predict different choices in any of the games. IQ is not correlated with other-regarding preferences even in a specification in which we do not control for parental education, suggesting that there is not a simple direct link between cognitive abilities and other-regarding preferences (not reported). The

\footnotetext{
${ }^{14}$ Note that our baseline correlation between parental education and other-regarding preferences holds also for the sub-sample for which we collected measures of IQ (results available upon request).
} 
magnitude of the coefficient for low parental education does not decrease once we control for health and cognitive abilities. ${ }^{15}$

Next, we study the importance of peer effects. In columns 1-4 of Panel B of Table 4, we study whether there is a link between choices in the games and structure of child's siblings. Neither number of child's siblings nor birth order is an important predictor of choices in any game. Finally, in columns 9-12, we control in a detailed way for the potential role of different characteristics of a child's classmates and teachers by controlling for class fixed effects. Note that class fixed effects absorb away any variation in parental education across classes so that the remaining variation distinguishes children within the same class. The main effect of low parental education is robust when controlling for 37 class fixed effects. Together, these results suggest that low parental education does not affect other-regarding preferences of children via their worse health, lower cognitive abilities or different characteristics of their peers and teachers.

\section{Parental Education and Child Cognitive Skills}

Less educated parents may invest less effort or be less efficient than more educated parents in teaching children social norms that enhance cooperation. If this were the case, the relationship between low parental education and a child's other-regarding preferences is likely to depend on the child's cognitive skills, because smarter children might be less dependent on the judgment and parenting practices of their parents. This prediction is tested in the following analysis.

We divide the sample into two sub-samples: children with low and high IQ, and repeat the regression analysis with choices in the games as dependent variables for these two subsamples separately. The results of this exercise are presented in Table 5. We observe a large and highly statistically significant negative effect of low parental education on the likelihood of sharing in the sub-sample of less smart children (columns 1 and 2 of Panel A): children of less educated parents are 35 percentage points less likely to share in the costly prosocial game compared to children of more educated parents. There is no such difference in the sub-sample of high-IQ children. We observe a similar pattern for the costless prosocial game. Thus, the gap in sharing is the most profound for children disadvantaged both in terms of the education of their parents as well as their own cognitive skills. Other-regarding preferences are not very

\footnotetext{
${ }^{15}$ In our sample parental education does not predict health status of children and it is only weakly positively correlated with cognitive skills (results available upon request).
} 
different for the children who have high cognitive skills or whose parents have high education or both.

Since our IQ measure is available only for a sub-sample of children, we use two alternative measures of child cognitive abilities as robustness checks of the previous finding. Table A3 reports results analogous to those presented in Table 5 but with sub-samples defined on the basis of children's grades from mathematics and teachers' assessments of children school performance, instead of IQ. Overall, we find similar results as in Table 5 independent of the measure we use to identify children with low cognitive skills.

\section{Do Parental Effects Emerge Early or Later in Childhood?}

Since our sample covers children from kindergarten to grade 5 in primary school, it allows us to explore developmental patterns of other-regarding preferences during the age range between 4-12 years. This is useful because (1) we can study which other-regarding preferences become more prevalent with age, suggesting a content of norms that children gradually acquire during socialization, and (2) we can investigate whether the gaps in otherregarding preferences emerge early or later during childhood.

We find strong age effects in both costly and costless prosocial games (Figure 1). The prevalence of egalitarian choices in the costly prosocial game is $28 \%$ for the younger group (4-7 years) and it increases to $57 \%$ for the older group (8-12 years). Similar increase in prosocial choices can be observed in the costless prosocial game, where the younger children choose the egalitarian option in $48 \%$ of cases, ${ }^{16}$ while it is $82 \%$ among the older children. The age effects estimated in the regression analysis are highly statistically significant (Table 3, columns 1-2 of Panel A). We do not find any relationship between age and frequency of egalitarian choices in the costly and costless envy games (Table 3, columns 3-4 of Panel A and Figure 2). Taking choices across individual games together reveals that older children become more altruistic and less spiteful (Panel B of Table 3 and Figure 3), while there is no monotonic age effect on the prevalence of inequality aversion, in line with E. Fehr, D. Rützler and M. Sutter (2011).

\footnotetext{
${ }^{16}$ Note that the frequency of egalitarian choices in the costless prosocial game among younger children is not statistically different from $50 \%$ and therefore is consistent both with purely random choice and with pure selfishness since selfish individuals should be indifferent between both choices. However, the frequency of egalitarian choices in the costly prosocial game among younger children equals $28 \%$ which is statistically different both from $50 \%$ (consistent with random choice) and $0 \%$ (consistent with selfish choice). The likelihood of sharing is around 20 percentage points greater in the costless prosocial game than in the costly prosocial game also for older children. Based on these results, we are confident that children in both age groups do not decide randomly.
} 
These age effects are interesting in the light of our previous results on the effects of parental education. While in general, children seem to acquire more altruistic and less spiteful behavior during the socialization process, children disadvantaged in terms of their parents' education and their own cognitive skills lag behind in precisely these types of behavior. This observation triggers the question when does the gap between the disadvantaged and other children arise. To explore this, Figures 4 and 5 depict the prevalence of egalitarian choices in costly and costless prosocial games among younger (4-7 years old) and older (8-12 years old) children divided into four groups according to the combination of low/high parental education and low/high cognitive skills. Among the older children, there is a large gap between those disadvantaged in terms of both their cognitive skills and parental education and children from the other three groups who have either high cognitive skills or high parental education, or both. While the frequency of pro-social choices is very similar for the latter three groups (on average $66 \%$ in the costly prosocial game and $91 \%$ in the costless prosocial game), the disadvantaged children choose the pro-social option in less than half of the cases $(30 \%$ in the costly prosocial game and $40 \%$ in the costless prosocial game). These figures are backed-up with regression analysis (Table 6) where the prevalence of other-regarding preferences is analyzed separately for the groups of younger and older children. Once controlling for age, gender and other measures of family background, we find that among the older group the disadvantaged children are 38 (48) percentage points less likely to share in the costly (costless) prosocial game.

We find weaker evidence that the gap in sharing behavior emerges already during early childhood (4-7 years). In the costly prosocial game we observe a similar pattern for younger children as for the older ones (coefficients for low parental education and low IQ are not statistically different between the samples of younger and older children). The evidence is less conclusive in the costless prosocial game (Figure 5), where among the younger children those with low educated parents and high IQ share much more than the other three groups, but among the older children, the (negatively) outstanding group is composed of children of less educated parents with low IQ.

\section{Conclusions}

In this paper, we study whether and how family background affects the formation of altruism, inequality aversion and spitefulness during childhood. Understanding these effects is 
important because altruism and inequality aversion help to establish and maintain cooperative outcomes, while spitefulness contributes to deterioration of cooperation, and thus, these preferences are of relevance for both individual successes as well as for the society's welfare.

The existing literature finds older children to take the welfare of others more into account (Fehr, Bernhard, and Rockenbach 2008; Harbaugh, Krause, and Liday 2003). This paper aims to be the first step towards understanding the role of family background in the formation of these preferences. We complement the experimental measures of other-regarding preferences with a survey instrument for parents and we also collect data about child height, school absence, grades, intelligence and siblings' composition, to uncover for which type of children parental background matters the most.

The main finding is that children from families with low educated parents are less altruistic and more spiteful, while mother's employment status and whether parents live separated or together does not seem to play a role. Moreover, the effect of parental education is robust to controlling for a rich set of child characteristics -- including age, gender, health, and cognitive abilities - as well as siblings' composition and class fixed effects. These results suggest that parental background does not affect other-regarding preferences via peer effects associated with school choice, worse health or cognitive abilities. In addition, we find the link with low parental education to be very strong and significant in the sub-sample of children who have low cognitive skills or grades relative to their peers, whereas it is muted if a child has high cognitive capacities on her own. Thus, the gap in pro-social preferences arises specifically for a group of children who are disadvantaged both in terms of the education of their parents as well as their own cognitive skills. Our data do not allow us to distinguish whether this is because lower parental education and child IQ together indicate lower genetic predispositions to acquire social norms, or because less educated parents are less efficient in instilling social norms in children, especially if the children have low IQ.

Our finding that children from families with low parental education are less likely to have preferences that value the welfare of others positively is potentially important for understanding persistent inequalities across social groups. The existing evidence demonstrating strong correlations between parental background and fundamental life outcomes such as individual education attainment, future labor market outcomes and participation in socially harmful activities such as crime (Bowles, Gintis, and Groves 2008) seems to be too high to be explained purely by differences in financial resources. This has motivated the enquiry about parental effects on the formation of skills and preferences (Bowles, Gintis, and Groves 2008; Cunha et al. 2006). Based on our findings, we speculate 
that part of the effect of family background could originate in differences how children are able or guided to acquire preferences that are helpful for promoting efficient social interactions in groups.

While we find it intriguing that developmental gaps in other-regarding preferences emerge early in childhood and persist during the age range we study (4-12 yrs), it is an open question for further research whether the developmental gaps persist further into adolescence and adulthood, or whether children from disadvantaged families eventually catch up. Nevertheless, it is noteworthy that gaps in other types of skills observed among children were found to be persistent and very hard to reduce later during the lifecycle (Cunha et al. 2006).

Recognizing that (1) other-regarding preferences develop during early childhood and (2) coming from disadvantaged family environment, especially if coupled with low child cognitive skills, affects these developmental processes, are important findings for those interested in exploring whether other-regarding preferences can be shaped by policy interventions. Interesting evidence is provided by the Perry Preschool Program, an experimental intervention for disadvantaged children aged 3-4 years in the US based on teacher visits at child homes. (Lawrence J. Schweinhart et al., 2005) show that 40 years later the adults who were treated during childhood have higher rates of school graduation, lower likelihood of being dependent on welfare assistance and fewer arrests than the control group. Our results suggest that there may be additional benefits of education interventions targeting disadvantaged children. The programs may help to close the gaps in other-regarding preferences, either by making deliberate efforts to instill preferences that accord with social norms, or by providing training in cognitive skills that seem to attenuate the effects of low parental education. Note, however, that while our evidence opens a possibility of these effects, a more definitive answer could be provided only by an evaluation of a program that would measure a wide range of child outcomes, including experimental measures of otherregarding preferences.

\section{REFERENCES}

Almås, Ingvild, Alexander W. Cappelen, Erik Ø Sørensen, and Bertil Tungodden. 2010. "Fairness and the Development of Inequality Acceptance." Science, 328(5982), 1176 78. 
Aughinbaugh, Alison, and Maury Gittleman. 2003. "Does Money Matter? A Comparison of the Effect of Income on Child Development in the United States and Great Britain." Journal of Human Resources, 38(2), 416-40.

Bartling, Bjorn, Ernst Fehr and Daniel Schunk. Forthcoming. "Health Effects on Children's Willingness to Compete." Experimental Economics.

Benenson, Joyce F., Joanna Pascoe, and Nicola Radmore. 2007. "Children's Altruistic Behavior in the Dictator Game." Evolution and Human Behavior, 28(3), 168-75.

Bettinger, Eric, and Robert Slonim. 2007. "Patience among Children." Journal of Public Economics, 91(1-2), 343-63.

Bolton, Gary E., and Axel Ockenfels. 2000. "Erc: A Theory of Equity, Reciprocity, and Competition." American Economic Review, 90(1), 166-93.

Borghans, Lex, Bart H. H. Golsteyn, James Heckman, and John Eric Humphries. 2011. "Identification Problems in Personality Psychology.” Maastrich University RM/11/025.

Bowles, Samuel. 2004. Microeconomics. Behavior, Institutions, and Evolution, New York. Princeton University Press.

Bowles, Samuel, Herbert Gintis, and Melissa Osborne Groves. 2008. Unequal Chances: Family Background and Economic Success. Princeton University Press.

Case, Anne, and Lawrence F. Katz. 1991. The Company You Keep: The Effects of Family and Neighborhood on Disadvantaged Youths. National Bureau of Economic Research Cambridge, Mass., USA.

Case, Anne, Darren Lubotsky, and Christina Paxson. 2002. "Economic Status and Health in Childhood: The Origins of the Gradient." American Economic Review, 92(5), 130834.

Charness, Gary, and Matthew Rabin. 2002. "Understanding Social Preferences with Simple Tests." Quarterly Journal of Economics, 117(3), 817-69.

Czech Statistical Office. 2010. "Statistical Yearbook of the Czech Republic 2010". http://www.czso.cz/csu/2010edicniplan.nsf/engpubl/0001-10-

Cunha, Flavio, and James J. Heckman. 2007. "The Technology of Skill Formation." American Economic Review, 31-47.

Cunha, Flavio, James J. Heckman; Lance Lochner and Dimitriy V. Masterov. 2006. "Interpreting the Evidence on Life Cycle Skill Formation." Handbook of the Economics of Education, 1, 697-812. 
Currie, Janet. 2009. "Healthy, Wealthy, and Wise: Socioeconomic Status, Poor Health in Childhood, and Human Capital Development." Journal of Economic Literature, 47(1), 87122.

Dixit, Avinash. 2009. "Governance Institutions and Economic Activity." American Economic Review, 99(1), 5-24.

Eckel, Catherine, Philip J. Grossman, Cathleen A. Johnson, Angela C. M. de Oliveira, Christian Rojas, and Rick Wilson. 2011. "On the Development of Risk Preferences: Experimental Evidence." CBEES Working Paper \# 2008-5.

Eisenberg, Nancy, and Richard A. Fabes. 1998. "Prosocial Development." Handbook of Child Psychology, 3, 701-78.

Evans, Gary W. 2004. "The Environment of Childhood Poverty." American Psychologist, 59(2), 77.

Falk, Armin, Ernst Fehr, and Urs Fischbacher. 2005. "Driving Forces Behind Informal Sanctions." Econometrica, 73(6), 2017-30.

Fehr, Ernst, Helen Bernhard, and Bettina Rockenbach. 2008. "Egalitarianism in Young Children." Nature, 454(7208), 1079-83.

Fehr, Ernst, and Urs Fischbacher. 2003. "The Nature of Human Altruism: Proximate Patterns and Evolutionary Origins." Nature, 425, 785-91.

Fehr, Ernst, Daniela Rützler, and Matthias Sutter. 2011. "The Development of Egalitarianism, Altruism, Spite and Parochialism in Childhood and Adolescence." IZA Discussion Paper 5530.

Fehr, Ernst, and Klaus M. Schmidt. 1999. "A Theory of Fairness, Competition, and Cooperation." Quarterly Journal of Economics, 114(3), 817-68.

Harbaugh, William. T., Kate Krause, and Steven J. Liday. 2003, "Bargaining by Children." University of Oregon Working Paper 2002-4.

Harbaugh, William T., Kate Krause, Steven Lidaym and Lise Vesterlund. Forthcoming. "Trust in Children." Trust, Reciprocity and Gains from Association: Interdisciplinary Lessons from Experimental Research. New York City. Russell Sage Foundation.

Heckman, James J. 2006. "Skill Formation and the Economics of Investing in Disadvantaged Children." Science, 312(5782), 1900.

Henrich, Joseph, Robert Boyd, Samuel Bowles, Colin Camerer, Ernst Fehr, Herbert Gintis, Richard McElreath, Michael Alvard, Abigail Barr, Jean Ensminger, Natalie Smith Henrich, Kim Hill, Francisco Gil-White, Michael Gurven, Frank W. Marlowe, 
John Q. Patton, and David Tracer. 2005. "“Economic Man” in Cross-Cultural Perspective: Behavioral Experiments in 15 Small-Scale Societies." Behavioral and Brain Sciences, 28(06), 795-815.

Herrmann, Benedikt, Christian Thoni, and Simon Gachter. 2008. "Antisocial Punishment across Societies." Science, 319(5868), 1362.

Loehlin, John. "Resemblance in Personality and Attitudes between Parents and Their Children: Genetic and Environmental Contributions," In Bowles Et Al (2005): Unequal Chance. Princeton: Princeton University Press.

Schweinhart, Lawrence J., Jeanne Montie, Zongping Xiang, William S. Barnett, Clive R. Belfield, and Milagros Nores. 2005. Lifetime Effects: The High/Scope Perry Preschool Study through Age 40. MI: High/Scope Press.

Sutter, Matthias, and Martin G. Kocher. 2007. "Trust and Trustworthiness across Different Age Groups." Games and Economic Behavior, 59(2), 364-82.

Sutter, Matthias, Martin G. Kocher, Daniela Rützler, and Stefan Trautmann. 2010. "Impatience and Uncertainty: Experimental Decisions Predict Adolescents' Field Behavior." IZA Discussion Paper \#5404. 


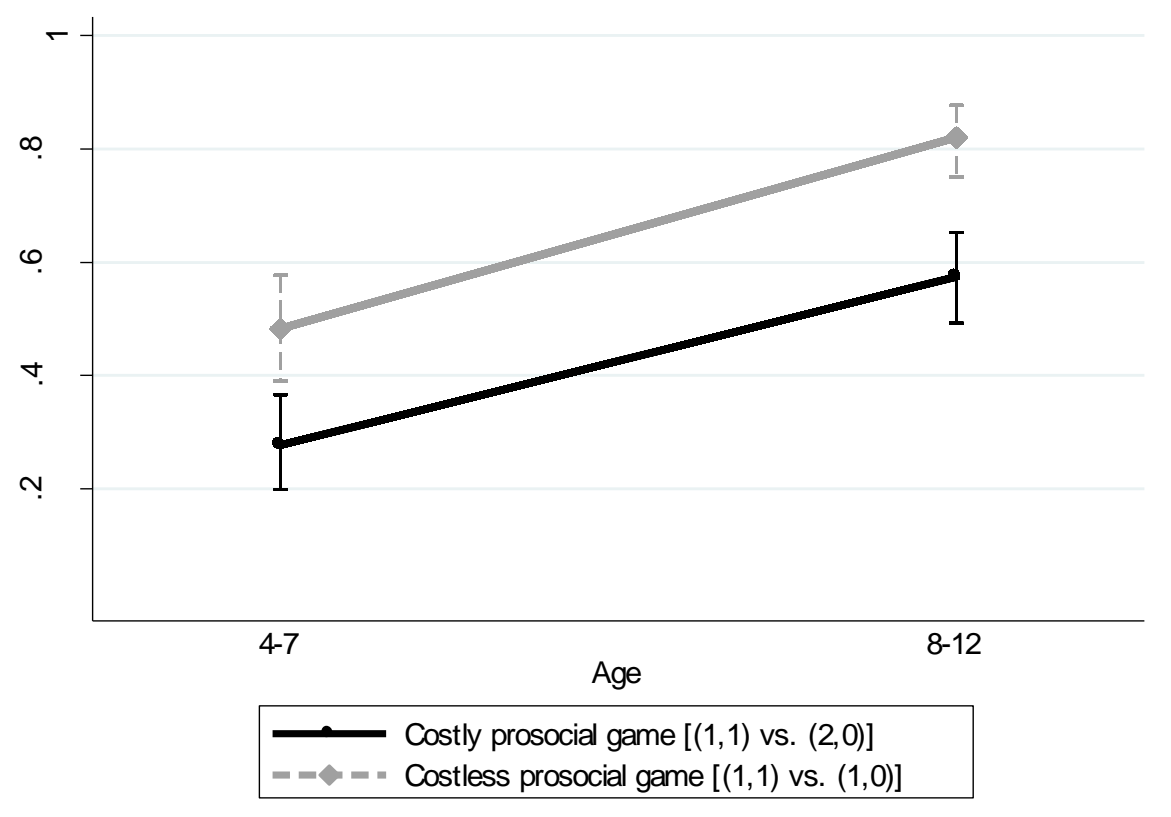

Figure 1. The Prevalence of Egalitarian Choices in Prosocial Games aCross Age Groups Note: Error bars provide 95\% exact confidence intervals.

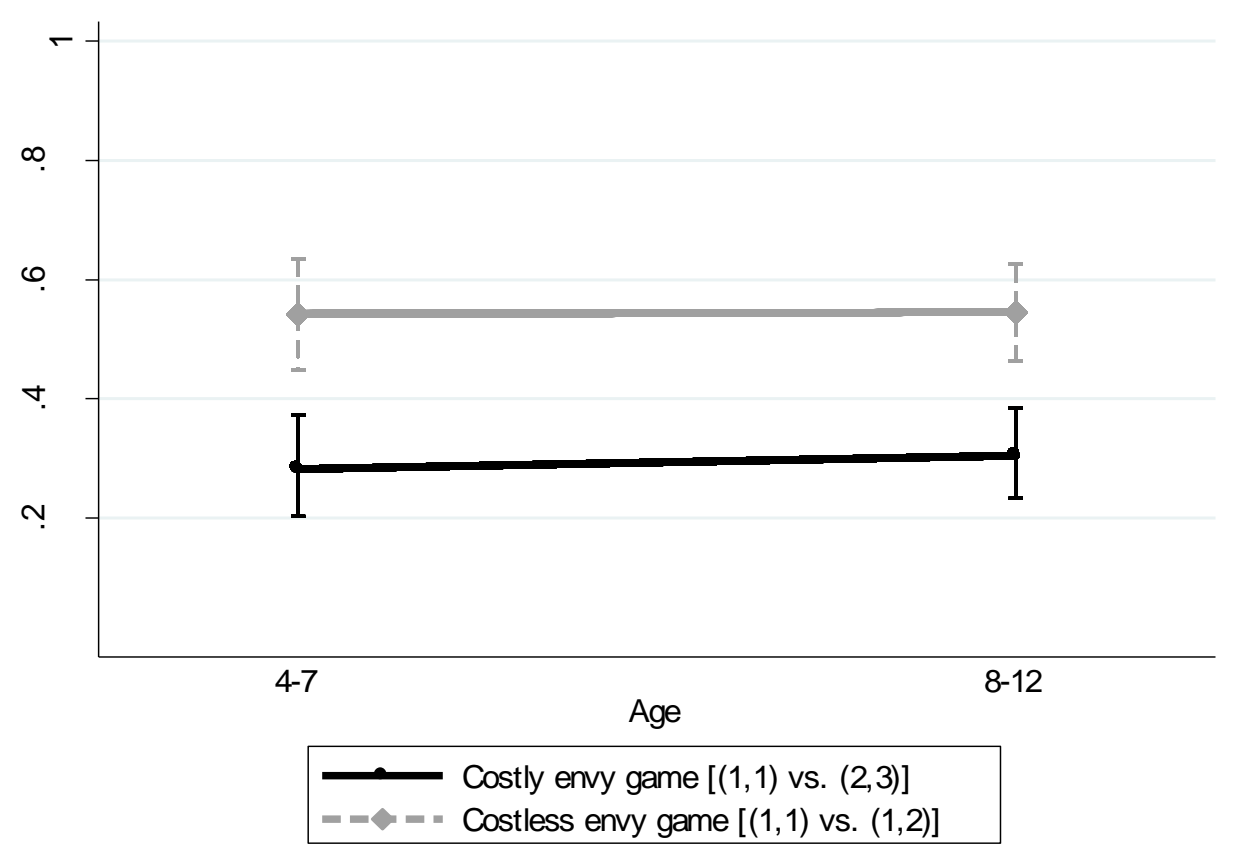

Figure 2. The Prevalence of Egalitarian Choices in Envy Games aCross Age Groups Note: Error bars provide 95\% exact confidence intervals. 


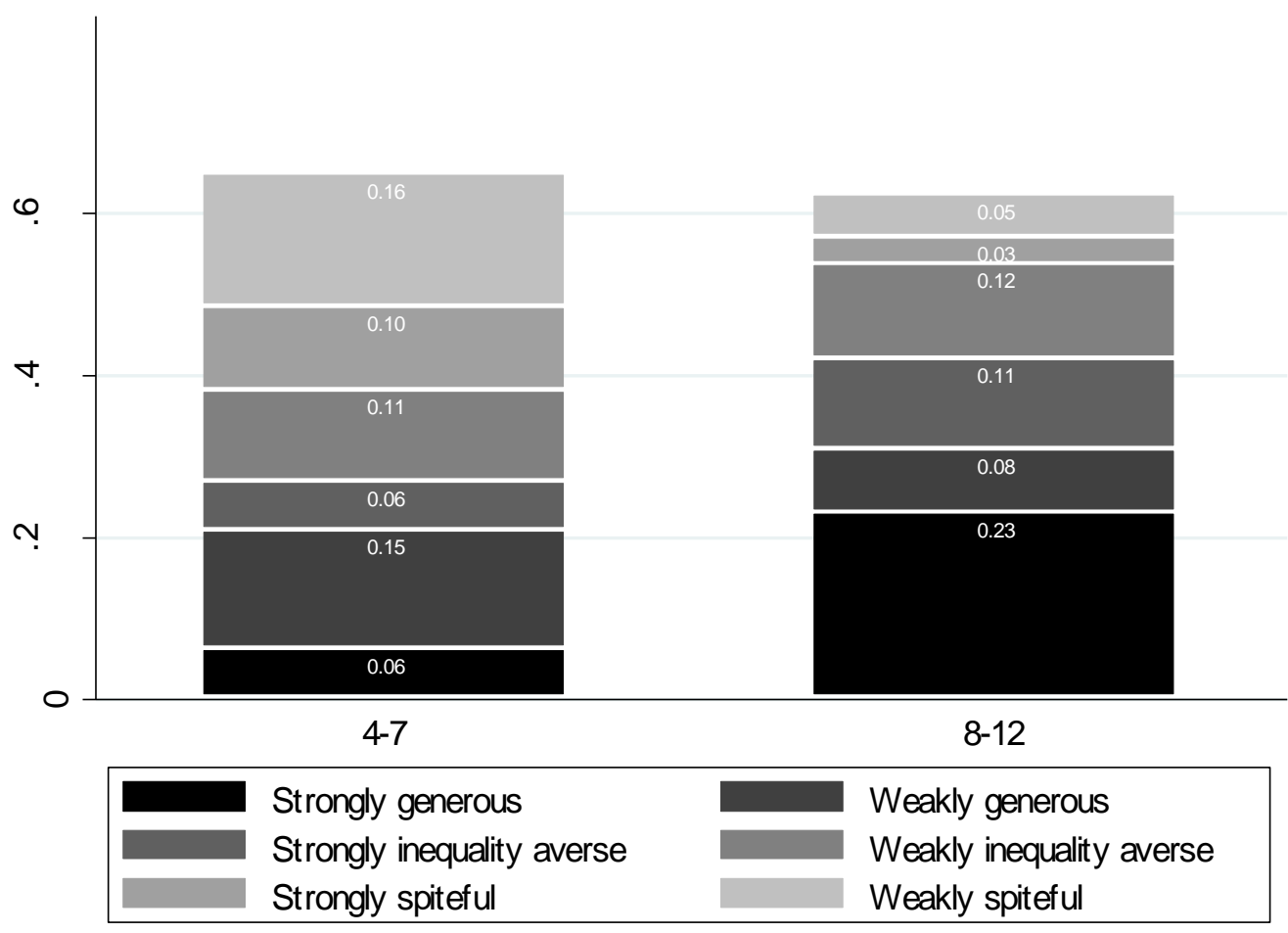

Figure 3. COMPOSITION OF OTHER-REgARDING TYPES ACROSS AgE GROUPS

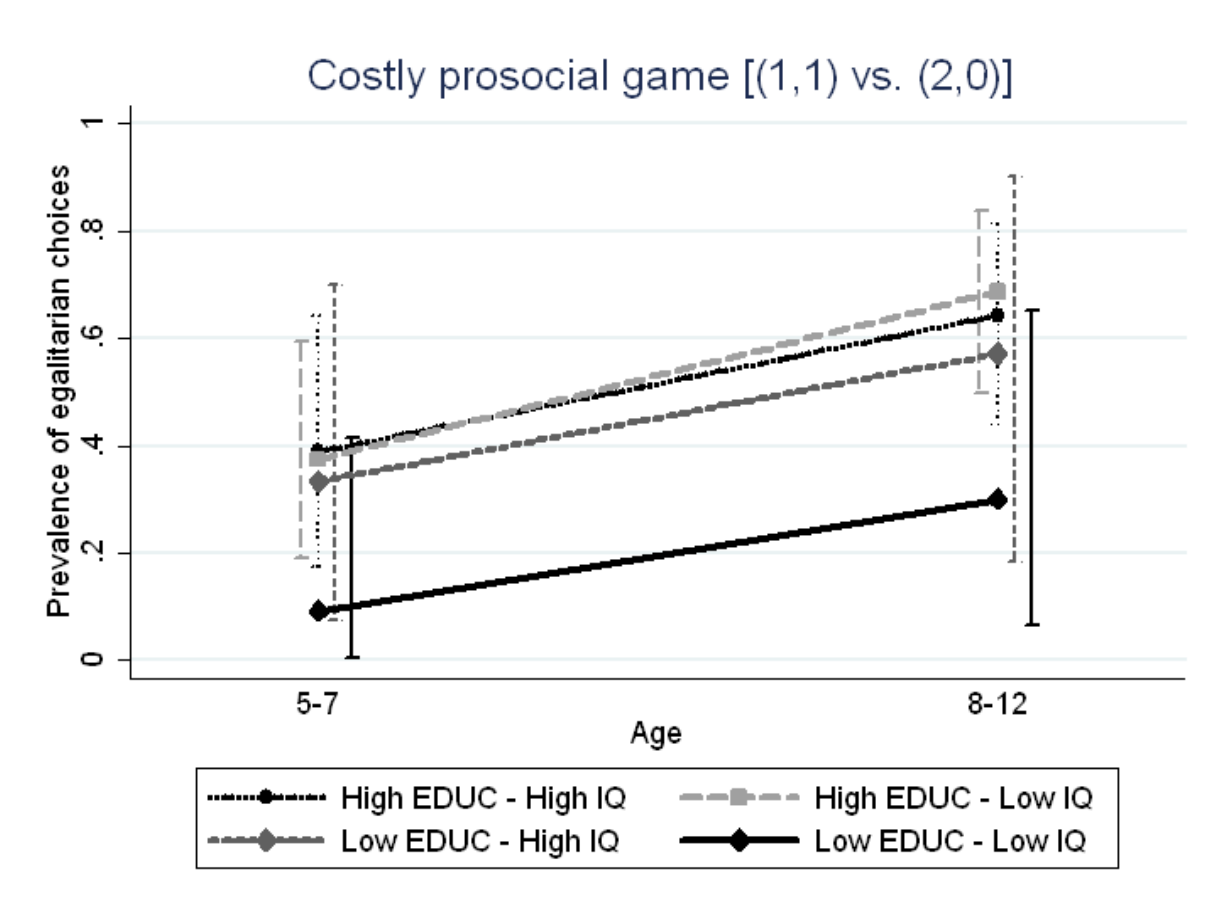

Figure 4. The Prevalence of Egalitarian Choices in Costly Prosocial Game across Parental BACKGROUND AND COGNITIVE ABILITIES

Note: Error bars provide $95 \%$ exact confidence intervals. 


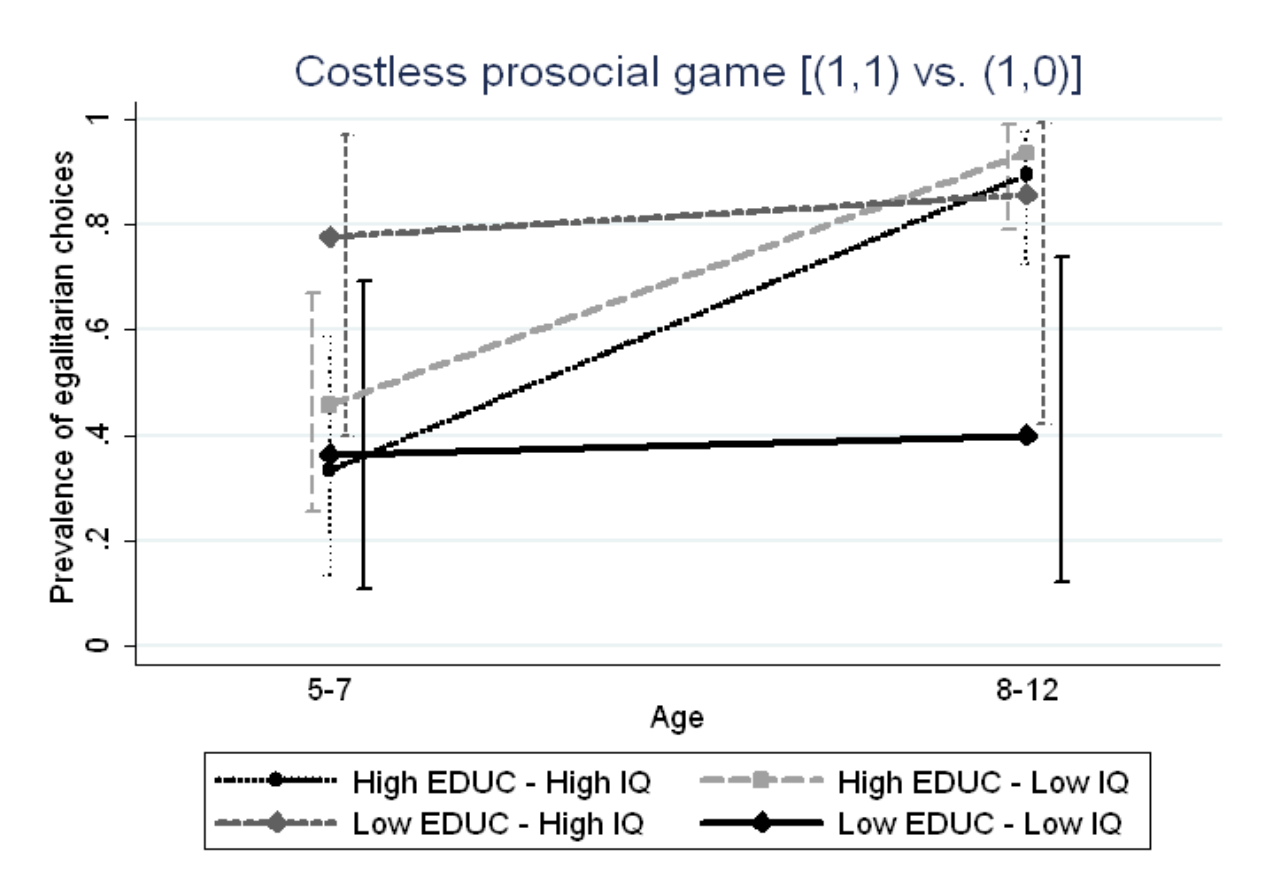

Figure 5. The Prevalence of Egalitarian Choices in Costless Prosocial Game across Parental BACKGROUND AND COGNITIVE ABILITIES

Note: Error bars provide $95 \%$ exact confidence intervals.

TABLE 1 - DEFINITIONS OF OTHER-REGARDING TYPES

\begin{tabular}{|c|c|c|c|c|}
\hline & $\begin{array}{l}\text { Egalitarian choic } \\
\text { Costly prosocial } \\
\text { game }\end{array}$ & $\begin{array}{l}\text { e in: } \\
\text { Costless } \\
\text { prosocial game }\end{array}$ & $\begin{array}{l}\text { Costly envy } \\
\text { game }\end{array}$ & $\begin{array}{l}\text { Costless envy } \\
\text { game }\end{array}$ \\
\hline & $(1,1)$ vs. $(2,0)$ & $(1,1)$ vs. $(1,0)$ & $(1,1)$ vs. $(2,3)$ & $(1,1)$ vs. $(1,2)$ \\
\hline strongly altruistic & 1 & 1 & 0 & 0 \\
\hline weakly altruistic & 0 & 1 & 0 & 0 \\
\hline strongly inequality averse & 1 & 1 & 1 & 1 \\
\hline weakly inequality averse & 0 & 1 & 0 & 1 \\
\hline strongly spiteful & 0 & 0 & 1 & 1 \\
\hline weakly spiteful & 0 & 0 & 0 & 1 \\
\hline
\end{tabular}


Panel A: Child's characteristics

Whole sample

Age (years)

Mean SD

Female

$7.829 \quad$ (2.116)

Low parental education

$0.505 \quad(0.501)$

Low IQ

$0.262 \quad(0.440)$

$0.571 \quad(0.497)$

Parents separated

$0.193 \quad(0.395)$

Mother not working fulltime

$0.489 \quad(0.501)$

Number of siblings

$1.062 \quad(0.721)$

Birth order

$1.524 \quad(0.500)$

High absence at school

$0.427 \quad(0.497)$

Below median height

$0.533 \quad(0.500)$

Panel B: Choices in the experimental games

Costly prosocial game (egalitarian choice)

$0.445 \quad(0.498)$

Costless prosocial game (egalitarian choice)

$0.675 \quad(0.469)$

Costly envy game (egalitarian choice)

$0.295 \quad(0.457)$

Costless envy game (egalitarian choice)

$0.544 \quad(0.499)$

Strongly altruistic

$0.156 \quad(0.364)$

Weakly altruistic

$0.108 \quad(0.311)$

Strongly inequality-averse

$0.089 \quad(0.286)$

Weakly inequality-averse

$0.115 \quad(0.320)$

Strongly spiteful

$0.063 \quad(0.244)$

Weakly spiteful

$0.100 \quad(0.301)$ 


\section{PANEL A: CHOICES IN THE GAMES}

$\begin{array}{lllll}\text { Dependent variable } & \begin{array}{l}\text { Costly } \\ \text { prosocial } \\ \text { game }\end{array} & \begin{array}{l}\text { Costless } \\ \text { prosocial } \\ \text { game }\end{array} & \begin{array}{l}\text { Costly envy } \\ \text { game }\end{array} & \begin{array}{l}\text { Costless } \\ \text { envy game }\end{array} \\ & (1) & (2) & (3) & (4) \\ \text { Low parental education } & -0.145^{* *} & -0.0630 & -0.0432 & 0.0181 \\ & (0.0625) & (0.0746) & (0.0496) & (0.0687) \\ \text { Parents separated } & 0.00209 & 0.00629 & -0.0130 & -0.0646 \\ \text { Mother not working fulltime } & (0.0749) & (0.0604) & (0.0626) & (0.0768) \\ & 0.0673 & -0.0354 & -0.0193 & -0.0139 \\ \text { Age } & (0.0547) & (0.0547) & (0.0673) & (0.0638) \\ & 0.0771 * * * & 0.0744 * * * & 0.0171 & -0.00525 \\ \text { Gender } & (0.0122) & (0.0118) & (0.0154) & (0.0178) \\ & 0.119 * & 0.00590 & -0.00306 & -0.0316 \\ \text { Observations } & (0.0593) & (0.0446) & (0.0641) & (0.0594) \\ & 267 & 267 & 264 & 265\end{array}$

PANEL B: OTHER-REGARDING TYPES

$\begin{array}{lllllll}\text { Dependent variable } & \begin{array}{l}\text { Strongly } \\ \text { altruistic }\end{array} & \begin{array}{l}\text { Weakly } \\ \text { altruistic }\end{array} & \begin{array}{l}\text { Strongly } \\ \text { inequality } \\ \text { averse }\end{array} & \begin{array}{l}\text { Weakly } \\ \text { inequality } \\ \text { averse }\end{array} & \begin{array}{l}\text { Strongly } \\ \text { spiteful }\end{array} & \begin{array}{l}\text { Weakly } \\ \text { spiteful }\end{array} \\ \text { Low parental education } & (1) & (2) & (3) & (4) & (5) & (6) \\ & -0.114 * * & 0.112 * * & -0.0445 & -0.0464 & -0.0296 & 0.120 * * \\ \text { Parents separated } & (0.0483) & (0.0449) & (0.0381) & (0.0455) & (0.0317) & (0.0458) \\ & 0.0121 & 0.0507 & -0.0401 & 0.0102 & 0.0549 & -0.0418 \\ \text { Mother not working fulltime } & (0.0469) & (0.0482) & (0.0313) & (0.0444) & (0.0528) & (0.0308) \\ & 0.0198 & 0.0345 & -0.00780 & -0.0363 & 0.0179 & 0.0383 \\ \text { Age } & (0.0462) & (0.0380) & (0.0427) & (0.0367) & (0.0333) & (0.0327) \\ \text { Gender } & 0.0419 * * * & -0.00978 & 0.0100 & -0.0123 & -0.00643 & -0.0221 * * * \\ & (0.0132) & (0.00997) & (0.00798) & (0.00997) & (0.00699) & (0.00552) \\ \text { Observations } & -0.0290 & -0.0107 & 0.0500 * & -0.0399 & -0.0380 & -0.0467 \\ & (0.0321) & (0.0334) & (0.0286) & (0.0391) & (0.0309) & (0.0357)\end{array}$

Notes: OLS, standard errors in parentheses, clustered at teacher level. The findings reported in this and the following tables are robust to using probit or logit models.

*** Significant at the 1 percent level.

** Significant at the 5 percent level.

* Significant at the 10 percent level. 


\begin{tabular}{|c|c|c|c|c|c|c|c|c|}
\hline Dependent variable & $\begin{array}{l}\text { Costly } \\
\text { prosocial } \\
\text { game }\end{array}$ & $\begin{array}{l}\text { Costless } \\
\text { prosocial } \\
\text { game }\end{array}$ & $\begin{array}{l}\text { Costly } \\
\text { envy game }\end{array}$ & $\begin{array}{l}\text { Costless } \\
\text { envy game }\end{array}$ & $\begin{array}{l}\text { Costly } \\
\text { prosocial } \\
\text { game }\end{array}$ & $\begin{array}{l}\text { Costless } \\
\text { prosocial } \\
\text { game }\end{array}$ & $\begin{array}{l}\text { Costly } \\
\text { envy game }\end{array}$ & $\begin{array}{l}\text { Costless } \\
\text { envy game }\end{array}$ \\
\hline & (1) & $(2)$ & (3) & (4) & $(5)$ & (6) & (7) & $(8)$ \\
\hline \multicolumn{9}{|c|}{ PANEL A: HEALTH AND COGNITIVE SKILLS } \\
\hline Low parental education & $\begin{array}{l}-0.189 \\
(0.137)\end{array}$ & $\begin{array}{l}-0.117 \\
(0.115)\end{array}$ & $\begin{array}{l}-0.0148 \\
(0.0962)\end{array}$ & $\begin{array}{l}-0.0360 \\
(0.153)\end{array}$ & $\begin{array}{l}-0.206 * * \\
(0.0762)\end{array}$ & $\begin{array}{l}-0.107 \\
(0.105)\end{array}$ & $\begin{array}{l}-0.0684 \\
(0.0658)\end{array}$ & $\begin{array}{l}0.0245 \\
(0.0850)\end{array}$ \\
\hline High absence at school & $\begin{array}{l}0.0406 \\
(0.0633)\end{array}$ & $\begin{array}{l}0.0346 \\
(0.0404)\end{array}$ & $\begin{array}{l}0.0747 \\
(0.0849)\end{array}$ & $\begin{array}{l}0.0469 \\
(0.134)\end{array}$ & & & & \\
\hline Below median height & $\begin{array}{l}0.0579 \\
(0.0577)\end{array}$ & $\begin{array}{l}-0.00518 \\
(0.0592)\end{array}$ & $\begin{array}{l}-0.0121 \\
(0.115)\end{array}$ & $\begin{array}{l}-0.138 \\
(0.0938)\end{array}$ & & & & \\
\hline Low IQ & & & & & $\begin{array}{l}-0.0393 \\
(0.0845)\end{array}$ & $\begin{array}{l}-0.0373 \\
(0.0734)\end{array}$ & $\begin{array}{l}-0.0330 \\
(0.113)\end{array}$ & $\begin{array}{l}0.00352 \\
(0.0483)\end{array}$ \\
\hline Observations & 108 & 108 & 106 & 107 & 137 & 138 & 136 & 136 \\
\hline \multicolumn{9}{|c|}{ PANEL B: PEER EFFECTS } \\
\hline Low parental education & $\begin{array}{l}-0.133 * * \\
(0.0629)\end{array}$ & $\begin{array}{l}-0.0744 \\
(0.0746)\end{array}$ & $\begin{array}{l}-0.0454 \\
(0.0501)\end{array}$ & $\begin{array}{l}0.0227 \\
(0.0710)\end{array}$ & $\begin{array}{l}-0.153 * * \\
(0.0680)\end{array}$ & $\begin{array}{l}-0.0365 \\
(0.0634)\end{array}$ & $\begin{array}{l}-0.0302 \\
(0.0660)\end{array}$ & $\begin{array}{l}0.0169 \\
(0.0738)\end{array}$ \\
\hline Number of siblings & $\begin{array}{l}0.0787 \\
(0.0540)\end{array}$ & $\begin{array}{l}-0.0343 \\
(0.0396)\end{array}$ & $\begin{array}{l}-0.0547 \\
(0.0598)\end{array}$ & $\begin{array}{l}-0.0396 \\
(0.0536)\end{array}$ & & & & \\
\hline Birth order & $\begin{array}{l}-0.0668 \\
(0.0747)\end{array}$ & $\begin{array}{l}0.0106 \\
(0.0720)\end{array}$ & $\begin{array}{l}0.0113 \\
(0.0631)\end{array}$ & $\begin{array}{l}-0.0458 \\
(0.0705)\end{array}$ & & & & \\
\hline Class fixed effects & no & no & no & no & yes & yes & yes & yes \\
\hline Observations & 265 & 265 & 262 & 263 & 267 & 267 & 264 & 265 \\
\hline R-squared & 0.141 & 0.124 & 0.014 & 0.011 & 0.245 & 0.264 & 0.167 & 0.119 \\
\hline
\end{tabular}

Notes: OLS, standard errors in parentheses. In all columns of Panel A and columns 1-4 of Panel B standard errors are clustered at teacher level; in columns 5-8 of Panel B we control for teacher fixed effects. In all columns of both Panels we control for other measures of family background (parents separated, mother not working fulltime), age and gender.

*** Significant at the 1 percent level.

** Significant at the 5 percent level.

* Significant at the 10 percent level. 


$\begin{array}{lllll}\text { Dependent variable } & \begin{array}{l}\text { Costly } \\ \text { prosocial } \\ \text { game }\end{array} & \begin{array}{l}\text { Costless } \\ \text { prosocial } \\ \text { game }\end{array} & \begin{array}{l}\text { Costly envy } \\ \text { game }\end{array} & \begin{array}{l}\text { Costless } \\ \text { envy gam }\end{array} \\ \text { PANEL A: LOW IQ SUB-SAMPLE } & (2) & (3) & (4) \\ \text { Low parental education } & -0.304^{* * * *} & -0.305^{* *} & -0.0528 & 0.0954 \\ & (0.100) & (0.142) & (0.0927) & (0.110) \\ \text { Observations } & 79 & 79 & 79 & 79 \\ \text { PANEL B: HIGH IQ SUB-SAMPLE } & -0.0578 & 0.162 & -0.106 & -0.0782 \\ \text { Low parental education } & (0.124) & (0.132) & (0.120) & (0.150) \\ & 58 & 59 & 57 & 57\end{array}$

Notes: OLS, standard errors in parentheses, clustered at teacher level. In all columns of both panels we control for other measures of family background (parents separated, mother not working fulltime), age and gender.

*** Significant at the 1 percent level.

** Significant at the 5 percent level.

* Significant at the 10 percent level. 
TABLE 6 - Other-REgarding PREFERENCES AND PARENTAL EdUCATION (Younger VS. OLDER CHILDREN)

\begin{tabular}{lllll}
\hline & & & \\
& $\begin{array}{l}\text { Costly } \\
\text { prosocial } \\
\text { game }\end{array}$ & $\begin{array}{l}\text { Costless } \\
\text { prosocial } \\
\text { game }\end{array}$ & $\begin{array}{l}\text { Costly } \\
\text { envy game }\end{array}$ & $\begin{array}{l}\text { Costless } \\
\text { envy gan }\end{array}$ \\
& $(1)$ & $(2)$ & $(3)$ & $(4)$ \\
PANEL A: SUB-SAMPLE OF YOUNGER CHILDREN (4-7 & YEARS OLD) \\
Low parental education \& Low IQ & -0.292 & 0.0241 & -0.228 & -0.0805 \\
& $(0.204)$ & $(0.289)$ & $(0.223)$ & $(0.138)$ \\
High parental education \& Low IQ & 0.0129 & 0.0943 & -0.161 & -0.0582 \\
& $(0.127)$ & $(0.0847)$ & $(0.137)$ & $(0.113)$ \\
Low parental education \& High IQ & -0.0786 & $0.342^{*}$ & -0.232 & -0.146 \\
& $(0.147)$ & $(0.179)$ & $(0.143)$ & $(0.236)$ \\
Observations & 61 & 61 & 61 & 61 \\
PANEL B: SUB-SAMPLE OF OLDER CHILDREN & $(8-12$ YEARS OLD) & \\
Low parental education \& Low IQ & $-0.330^{*}$ & $-0.413 *$ & -0.00428 & 0.121 \\
& $(0.164)$ & $(0.225)$ & $(0.242)$ & $(0.178)$ \\
High parental education \& Low IQ & 0.0239 & 0.0459 & 0.0832 & -0.0370 \\
& $(0.107)$ & $(0.0597)$ & $(0.188)$ & $(0.0996)$ \\
Low parental education \& High IQ & -0.0359 & -0.0269 & 0.0237 & 0.0164 \\
& $(0.182)$ & $(0.188)$ & $(0.184)$ & $(0.257)$ \\
Observations & 76 & 77 & 75 & 75
\end{tabular}

Notes: OLS, standard errors in parentheses, clustered at teacher level. In all columns of both panels we control for other measures of family background (parents separated, mother not working fulltime), age and gender.

*** Significant at the 1 percent level.

** Significant at the 5 percent level.

* Significant at the 10 percent level. 
APPENDIX

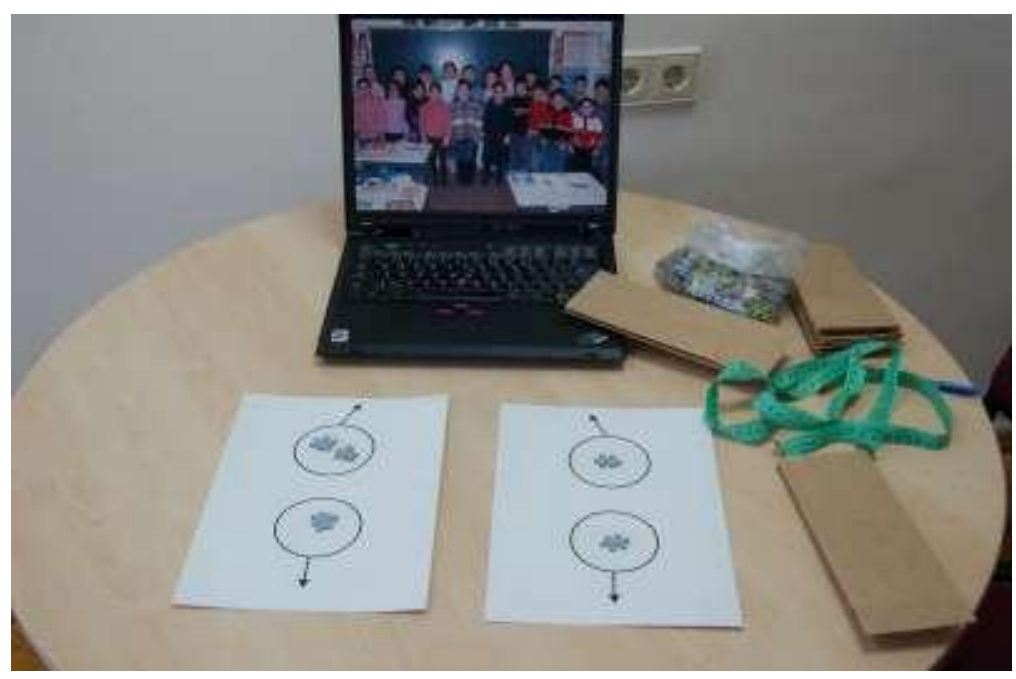

FiguRE A1: CHOICE SITUATION

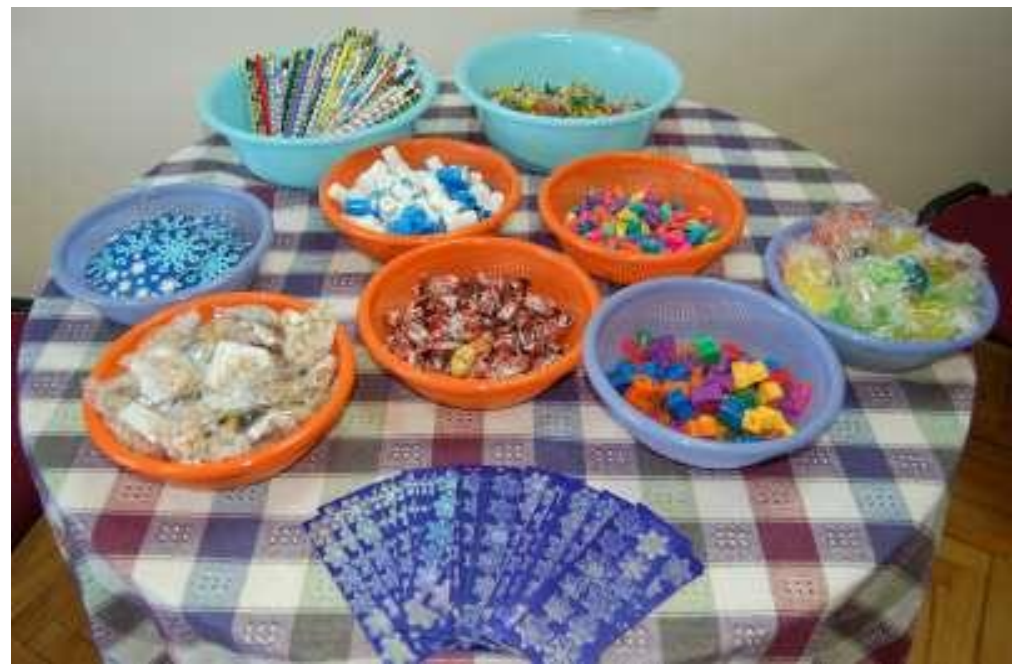

FIGURE A2: EXPERIMENTAL SHOP 
Which answer fits in the missing space to complete the pattern?

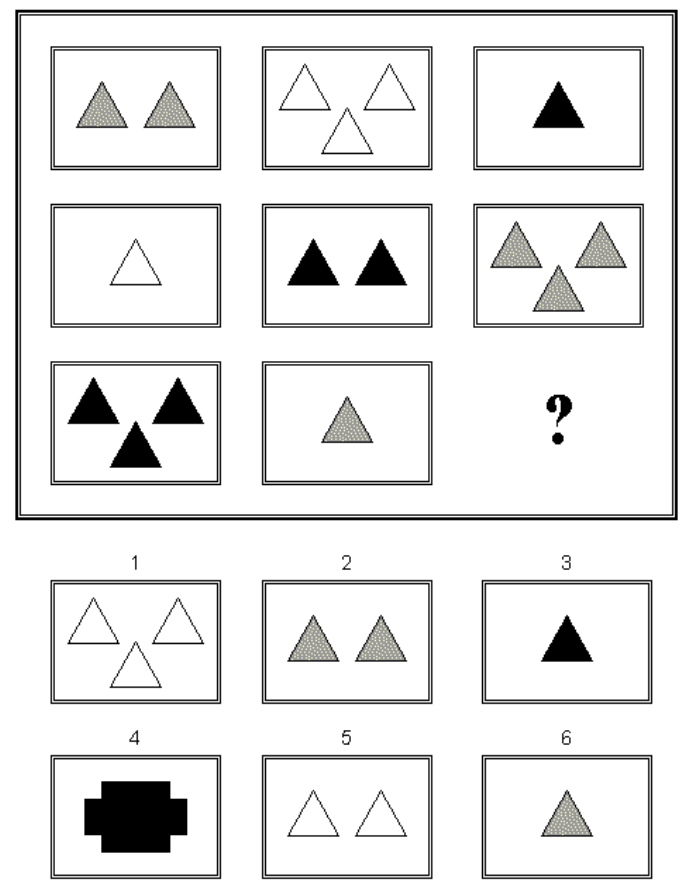

FIGURE A3 - AN EXAMPLE OF A RAVEN's MATRIX USED TO MEASURE IQ 
TABLE A.1 - OTHER-REgARDING PREFERENCES, MOTHER's EDUCATION AND FATHER'S EDUCATION

\section{PANEL A: CHOICES IN THE GAMES AND MOTHER'S EDUCATION}

$\begin{array}{lllll}\text { Dependent variable } & \begin{array}{l}\text { Costly } \\ \text { prosocial } \\ \text { game }\end{array} & \begin{array}{l}\text { Costless } \\ \text { prosocial } \\ \text { game }\end{array} & \begin{array}{l}\text { Costly envy } \\ \text { game }\end{array} & \begin{array}{l}\text { Costless } \\ \text { envy game }\end{array} \\ & (1) & (2) & (3) & (4) \\ \text { Low mother's education } & -0.144^{* *} & -0.0629 & -0.0451 & 0.0208 \\ & (0.0626) & (0.0747) & (0.0495) & (0.0694) \\ \text { Observations } & 266 & 266 & 263 & 264\end{array}$

PANEL B: CHOICES IN THE GAMES AND FATHER'S EDUCATION

$\begin{array}{lllll}\text { Dependent variable } & \begin{array}{l}\text { Costly } \\ \text { prosocial } \\ \text { game }\end{array} & \begin{array}{l}\text { Costless } \\ \text { prosocial } \\ \text { game }\end{array} & \begin{array}{l}\text { Costly envy } \\ \text { game }\end{array} & \begin{array}{l}\text { Costless } \\ \text { envy game }\end{array} \\ & (1) & (2) & (3) & (4) \\ \text { Low father's education } & -0.140 * * & -0.0217 & -0.0533 & 0.0228 \\ & (0.0660) & (0.0676) & (0.0458) & (0.0765) \\ \text { Observations } & 257 & 257 & 254 & 255\end{array}$

PANEL C: OTHER-REGARDING TYPES AND MOTHER'S EDUCATION

$\begin{array}{lllllll}\text { Dependent variable } & \begin{array}{l}\text { Strongly } \\ \text { altruistic }\end{array} & \begin{array}{l}\text { Weakly } \\ \text { altruistic }\end{array} & \begin{array}{l}\text { Strongly } \\ \text { inequality } \\ \text { averse }\end{array} & \begin{array}{l}\text { Weakly } \\ \text { inequality } \\ \text { averse }\end{array} & \begin{array}{l}\text { Strongly } \\ \text { spiteful }\end{array} & \begin{array}{l}\text { Weakly } \\ \text { spiteful }\end{array} \\ \text { Low mother's education } & (1) & (2) & (3) & (4) & (5) & (6) \\ & -0.116^{* *} & 0.112^{* *} & -0.0449 & -0.0469 & -0.0303 & 0.120^{* *} \\ \text { Observations } & (0.0484) & (0.0451) & (0.0383) & (0.0456) & (0.0316) & (0.0458) \\ & 261 & 261 & 261 & 261 & 261 & 261\end{array}$

PANEL D: OTHER-REGARDING TYPES AND FATHER'S EDUCATION

$\begin{array}{lllllll}\text { Dependent variable } & \begin{array}{l}\text { Strongly } \\ \text { altruistic }\end{array} & \begin{array}{l}\text { Weakly } \\ \text { altruistic }\end{array} & \begin{array}{l}\text { Strongly } \\ \text { inequality } \\ \text { averse }\end{array} & \begin{array}{l}\text { Weakly } \\ \text { inequality } \\ \text { averse }\end{array} & \begin{array}{l}\text { Strongly } \\ \text { spiteful }\end{array} & \begin{array}{l}\text { Weakly } \\ \text { spiteful }\end{array} \\ \text { Low father's education } & (1) & (2) & (3) & (4) & (5) & (6) \\ & -0.107^{* *} & 0.118^{* *} & -0.0395 & -0.0449 & -0.0438 & 0.115^{* *} \\ \text { Observations } & (0.0520) & (0.0487) & (0.0398) & (0.0471) & (0.0290) & (0.0434) \\ & 252 & 252 & 252 & 252 & 252 & 252\end{array}$

Notes: OLS, standard errors in parentheses, clustered at teacher level. In all columns of all Panels we control for other measures of family background (parents separated, mother not working fulltime), age and gender.

*** Significant at the 1 percent level.

** Significant at the 5 percent level.

* Significant at the 10 percent level. 
TABle A.2 - Heckman SAmple Selection Model (Estimates with Correction for PARENTAL NON-RESPONSE)

\section{PANEL A: CHOICES IN THE GAMES}

Dependent variable

$\begin{array}{ll}\text { Costly } & \text { Costless } \\ \text { prosocial } & \text { prosocial } \\ \text { game } & \text { game }\end{array}$

Costly envy Costless

game envy game

(1) (2) (3) (4)

Low parental education

$\begin{array}{llll}-0.145 * * & -0.0631 & -0.0429 & 0.0183\end{array}$

$\begin{array}{llll}(0.0644) & (0.0607) & (0.0635) & (0.0688)\end{array}$

Parents separated

$\begin{array}{llll}0.00239 & 0.00675 & -0.0134 & -0.0668\end{array}$

$\begin{array}{llll}(0.0730) & (0.0686) & (0.0720) & (0.0782)\end{array}$

Mother not working fulltime

$\begin{array}{llll}0.0639 & -0.0444 & -0.0162 & -0.00264\end{array}$

Age

$\begin{array}{llll}(0.0584) & (0.0551) & (0.0574) & (0.0625)\end{array}$

$0.0644 * * * \quad 0.0432 * * \quad 0.0285 \quad 0.0343$

Gender

$\begin{array}{llll}(0.0212) & (0.0203) & (0.0215) & (0.0236)\end{array}$

$\begin{array}{llll}0.104 * & -0.0303 & 0.0104 & 0.0181\end{array}$

$\begin{array}{llll}(0.0603) & (0.0595) & (0.0598) & (0.0689)\end{array}$

Observations

267 267

264

265

\section{PANEL B: OTHER-REGARDING TYPES}

$\begin{array}{lllllll}\text { Dependent variable } & \begin{array}{l}\text { Strongly } \\ \text { altruistic }\end{array} & \begin{array}{l}\text { Weakly } \\ \text { altruistic }\end{array} & \begin{array}{l}\text { Strongly } \\ \text { inequality } \\ \text { averse }\end{array} & \begin{array}{l}\text { Weakly } \\ \text { inequality } \\ \text { averse }\end{array} & \begin{array}{l}\text { Strongly } \\ \text { spiteful }\end{array} & \begin{array}{l}\text { Weakly } \\ \text { spiteful }\end{array} \\ \text { Low parental education } & (1) & (2) & (3) & (4) & (5) & (6) \\ & -0.114 * * & 0.112 * * * & -0.0448 & -0.0459 & -0.0294 & 0.121 * * * \\ \text { Parents separated } & (0.0490) & (0.0425) & (0.0401) & (0.0450) & (0.0343) & (0.0406) \\ & 0.0125 & 0.0517 & -0.0396 & 0.00926 & 0.0546 & -0.0437 \\ \text { Mother not working fulltime } & (0.0560) & (0.0485) & (0.0458) & (0.0513) & (0.0391) & (0.0463) \\ \text { Age } & 0.0179 & 0.0300 & -0.0101 & -0.0320 & 0.0195 & 0.0465 \\ & (0.0444) & (0.0385) & (0.0364) & (0.0408) & (0.0311) & (0.0369) \\ \text { Gender } & 0.0350 * * & -0.0261 * & 0.00177 & 0.00317 & -0.000628 & 0.00769 \\ & (0.0165) & (0.0146) & (0.0135) & (0.0154) & (0.0115) & (0.0149) \\ \text { Observations } & -0.0379 & -0.0316 & 0.0394 & -0.0201 & -0.0306 & -0.00850 \\ & (0.0465) & (0.0414) & (0.0382) & (0.0435) & (0.0326) & (0.0426)\end{array}$

Notes: Heckman 2-stage sample selection model, standard errors in parentheses.

Selection variables are age, gender, grade, and height.

*** Significant at the 1 percent level.

** Significant at the 5 percent level.

* Significant at the 10 percent level. 
TABle A.3 -SChOOL PERFormance, PARENTAL EdUCATION ANd CHOICES IN THE GAMES

$\begin{array}{llll} & \text { Costly } & \text { Costless } & \\ \text { prosocial } & \begin{array}{l}\text { prosocial } \\ \text { game }\end{array} & \begin{array}{l}\text { Costly envy Costless } \\ \text { game }\end{array} & \text { game envy game }\end{array}$
(1)
(2)
(3)
(4)

PANEL A: MATH GRADE WORSE THAN "A"

$\begin{array}{lllll}\text { Low parental education } & -0.350 * * * & -0.163 & 0.311 * * * & 0.144 \\ & (0.0956) & (0.170) & (0.0849) & (0.167) \\ \text { Observations } & 38 & 39 & 38 & 38\end{array}$

PANEL B: MATH GRADE "A"

$\begin{array}{lllll}\text { Low parental education } & -0.00282 & -0.177 & -0.00335 & 0.202\end{array}$

$\begin{array}{lllll} & (0.164) & (0.176) & (0.124) & (0.14 \\ \text { Observations } & 90 & 90 & 89 & 89\end{array}$

PANEL C: TEACHER ASSESSMENT - LOW PERFORMERS

$\begin{array}{lllll}\text { Low parental education } & -0.363^{* * *} & -0.225^{*} & 0.166 & 0.0453 \\ & (0.127) & (0.118) & (0.120) & (0.135) \\ \text { Observations } & 88 & 87 & 87 & 87 \\ \text { PANEL D: TEACHER ASSESSMENT }- \text { HIGH PERFORMERS } & \\ \text { Low parental education } & -0.0678 & 0.00743 & -0.195 & 0.115 \\ & (0.132) & (0.0981) & (0.133) & (0.134) \\ \text { Observations } & 107 & 108 & 106 & 107\end{array}$

Notes: OLS, standard errors in parentheses. In all columns of Panels A and B standard errors are clustered at teacher level. In all columns of panels $\mathrm{C}$ and D we control for teacher fixed effects. In all columns of all panels we control for other measures of family background (parents separated, mother not working fulltime), age and gender.

*** Significant at the 1 percent level.

** Significant at the 5 percent level.

* Significant at the 10 percent level. 


\section{Working Paper Series}

ISSN 1211-3298

Registration No. (Ministry of Culture): E 19443

Individual researchers, as well as the on-line and printed versions of the CERGE-EI Working Papers (including their dissemination) were supported from the European Structural Fund (within the Operational Programme Prague Adaptability), the budget of the City of Prague, the Czech Republic's state budget and the following institutional grants:

- Center of Advanced Political Economy Research [Centrum pro pokročilá politickoekonomická studia], No. LC542, (2005-2011);

- Economic Aspects of EU and EMU Entry [Ekonomické aspekty vstupu do Evropské unie a Evropské měnové unie], No. AVOZ70850503, (2005-2011);

- Economic Impact of European Integration on the Czech Republic [Ekonomické dopady evropské integrace na ČR], No. MSM0021620846, (2005-2011);

Specific research support and/or other grants the researchers/publications benefited from are acknowledged at the beginning of the Paper.

(c) Michal Bauer, Julie Chytilová, and Barbara Pertold-Gebicka, 2011

All rights reserved. No part of this publication may be reproduced, stored in a retrieval system or transmitted in any form or by any means, electronic, mechanical or photocopying, recording, or otherwise without the prior permission of the publisher.

Published by

Charles University in Prague, Center for Economic Research and Graduate Education (CERGE) and

Economics Institute ASCR, v. v. i. (EI)

CERGE-El, Politických vězňů 7, 11121 Prague 1, tel.: +420 224005 153, Czech Republic.

Printed by CERGE-EI, Prague

Subscription: CERGE-EI homepage: http://www.cerge-ei.cz

Phone: + 420224005153

Email: office@cerge-ei.cz

Web: http://www.cerge-ei.cz

Editor: Michal Kejak

Editorial board: Jan Kmenta, Randall Filer, Petr Zemčík

The paper is available online at http://www.cerge-ei.cz/publications/working_papers/.

ISBN 978-80-7343-253-9 (Univerzita Karlova. Centrum pro ekonomický výzkum a doktorské studium)

ISBN 978-80-7344-245-3 (Národohospodářský ústav AV ČR, v. v. i.) 
CERGE-EI

P.O.BOX 882

Politických vězňů 7

11121 Praha 1

Czech Republic http://www.cerge-ei.cz 